\title{
Oxidative stress status and reproductive performance of sows during gestation and lactation under different thermal environments
}

\author{
Yan Zhao ${ }^{1,2}$ and Sung Woo Kim ${ }^{2, *}$
}

* Corresponding Author: Sung Woo Kim Tel: +1-919-513-1494, Fax: +1-919-515-6884,

E-mail: sungwoo_kim@ncsu.edu

'Department of Animal Science and Technology, Shanxi Agricultural University, Taigu, Shanxi 030801, China

2 Department of Animal Science, North Carolina State University, Raleigh, NC 27606, USA

\section{ORCID}

Yan Zhao

https://orcid.org/0000-0002-4424-8329

Sung Woo Kim

https://orcid.org/0000-0003-4591-1943

Submitted Apr 23, 2019; Revised Jun 18, 2019; Accepted Sept 18, 2019
Objective: Two experiments were conducted using 28 healthy multiparous sows to evaluate the oxidative stress status and reproductive performance of sows during gestation and lactation under different thermal environments.

Methods: Fourteen multiparous sows were used in Exp. 1 under a high thermal environment, and the other 14 multiparous sows were used in Exp. 2 under a moderate thermal environment. In both experiments, reproductive performances of sows were recorded. Plasma samples were collected on d 35, 60, 90, and 109 of gestation, and d 1 and 18 of lactation for malondialdehyde, protein carbonyls, 8-hydroxy-deoxyguanosine, immunoglobulin $g$ (IgG), and IgM analysis.

Results: For sows in Exp. 1, plasma malondialdehyde concentration on d 109 of gestation tended to be greater $(\mathrm{p}<0.05)$ than it on $\mathrm{d} 18$ of lactation. Plasma concentration of protein carbonyl on $\mathrm{d} 109$ of gestation was the greatest $(\mathrm{p}<0.05)$ compared with all the other days. Plasma concentrations of 8-hydroxy-deoxyguanosine on $\mathrm{d} 109$ of gestation was greater $(\mathrm{p}<$ 0.05) than $\mathrm{d} 18$ of lactation in Exp. 1. For sows in Exp. 2, there was no difference of malondialdehyde and protein carbonyl concentration during gestation and lactation. In both Exp. 1 and 2, litter size and litter weight were found to be negatively correlated with oxidative stress indicators.

Conclusion: Sows under a high thermal environment had increased oxidative stress during late gestation indicating that increased oxidative damage to lipid, protein, and DNA could be one of the contributing factors for reduced reproductive performance of sows in this environment. This study indicates the importance of providing a moderate thermal environment to gestating and lactating sows to minimize the increase of oxidative stress during late gestation which can impair reproductive outcomes.

Keywords: Gestation; High Thermal Environment; Lactation; Oxidative Stress; Sow

\section{INTRODUCTION}

Reactive oxygen species (ROS) including superoxide anion $\left(\mathrm{O}_{2}{ }^{-*}\right)$, hydroxyl radical ('OH), and hydrogen peroxide $\left(\mathrm{H}_{2} \mathrm{O}_{2}\right)$ are produced during biochemical processes within an animal's body [1]. If the balance between the production of ROS and antioxidant defense is disturbed, the animal can suffer from oxidative stress. Accumulation of ROS could react with biological macromolecules such as proteins, lipids, and nucleic acids, resulting in lipid peroxidation, protein damage, and DNA damage [2,3]. In sows, external factors such as social stress and environmental stressors can lead to increased oxidative stress [4,5]. Zhao et al [5] studied the oxidative stress status of gestating and lactating sows under different gestational housing systems and social ranks. The results showed that sows under intense social stress could increase oxidative stress level during gestation and lactation [5]. Bottje et al [4] showed that environmental stressors such as high dust and ammonia levels in poultry 
house environment can cause oxidative stress in lung lining fluid of broilers.

Heat stress is another important environmental stressor to animal's reproductive performance especially during summer months in tropical and subtropical regions of the world. It has a significant negative impact on reproductive performance of sows including impaired embryonic development [6], reduced feed intake and milk production in sows $[7,8]$, and delayed puberty of gilts [9], which result in summer infertility and productivity losses that amount to millions of dollars. In the last decades, genetic improvement of sows for high reproductive performance results in increased metabolic heat production which makes sows more susceptible to the high thermal environment $[10,11]$. Previous studies found that sows were under severe catabolic status during late gestation and lactation $[12,13]$, and their oxidative stress levels increased during the same period [14]. However, the negative impact of high thermal environment on sow's oxidative stress status have not been well studied, and it is not known if oxidative stress status is related to reproductive performance of sows under different thermal environments. Therefore, we hypothesized that oxidative stress status of sows could elevate during late gestation and lactation when sows were housed under high thermal environment, and the elevated oxidative stress could be detrimental to the reproductive performance of sows. Thus, the objective of this study was to investigate oxidative stress status and its relationship with reproductive performance of sows during gestation and lactation under moderate and high thermal environments.

\section{MATERIALS AND METHODS}

\section{Animal care}

Procedures used in this study were reviewed and approved by the North Carolina State University Animal Care and Use Committee.

\section{Animals and experimental design}

Two experiments were carried out using 28 healthy multiparous sows at the North Carolina State University Swine Educational Unit (Raleigh, NC, USA), in the summer (Exp. 1 , June to August with average daily maximum and minimum temperature of $30.3^{\circ} \mathrm{C} \pm 2.9^{\circ} \mathrm{C}$ and $24.8^{\circ} \mathrm{C} \pm 2.2^{\circ} \mathrm{C}$ in the gestation building, and $30.9^{\circ} \mathrm{C} \pm 2.6^{\circ} \mathrm{C}$ and $22.1^{\circ} \mathrm{C} \pm 1.8^{\circ} \mathrm{C}$ in the farrowing building, respectively) and winter (Exp. 2, November to January with the average daily maximum and minimum temperature of $16.7^{\circ} \mathrm{C} \pm{ }^{\circ} \mathrm{C}$ and $11.9^{\circ} \mathrm{C} \pm 3.0^{\circ} \mathrm{C}$ in the gestation building, and $22.3^{\circ} \mathrm{C} \pm 2.0^{\circ} \mathrm{C}$ and $20.4^{\circ} \mathrm{C} \pm 2.1^{\circ} \mathrm{C}$ in the farrowing building, respectively). In Exp. 1, 14 multiparous sows (initial body weight [BW], $245.7 \pm 38.7 \mathrm{~kg}$; parity, 5.8 \pm 3.2 ; Landrace $\times$ Large White) were selected and assigned to a high thermal environment on d 35 of gestation. In Exp. 2, the other group of 14 multiparous sows (initial BW, 243.2 \pm $30.3 \mathrm{~kg}$; parity, $5.1 \pm 1.3$; Landrace $\times$ Large White) were selected and assigned to a moderate thermal environment on $\mathrm{d}$ 35 of gestation. Sows from both experiments were housed in the same gestation and farrowing buildings and managed with standard procedures. A negative pressure system was used to ventilate the gestation building with four 1,100-rpm, $61-\mathrm{cm}$ wall fans. The farrowing building had an evaporative cooling system and two $1,100-\mathrm{rpm}, 61-\mathrm{cm}$ wall fans. Water flow through the evaporative cooling system was controlled by an on-off thermostat which was set at $25^{\circ} \mathrm{C}$, and one gas heater was provided during winter season in the farrowing room. The thermal environment inside the facilities was monitored hourly using data loggers (Tinytag Plus 2, TPG4500, Gemini Data Loggers, Chichester, UK) to measure temperature and relative humidity. Average hourly ambient temperature and temperature-humidity index (THI) within a day in the gestation and farrowing buildings in Exp. 1 and 2 were showed in Figure 1 and 2, respectively. In Exp. 1 , sows were exposed to an ambient temperature above $25^{\circ} \mathrm{C}$ for an average of $17 \mathrm{~h}$ and $14 \mathrm{~h}$ per day in gestation building and farrowing building, respectively (Figure 1A). The hourly THI was ranged from 72 to 78 in the gestation building and from 69 to 83 in the farrowing building (Figure 1B). On the other hand, sows in Exp. 2 were kept in a moderate thermal environment as shown in Figure 2. The hourly ambient temperature was from $12^{\circ} \mathrm{C}$ to $17^{\circ} \mathrm{C}$ in the gestation building and $19^{\circ} \mathrm{C}$ to $21^{\circ} \mathrm{C}$ in the farrowing building (Figure $2 \mathrm{~A})$. The hourly THI was ranged from 54 to 61 in the gestation building and from 65 to 67 in the farrowing building (Figure 2B).

The estrus of weaning sows in these 2 experiments was detected daily by the immobilization response as a reaction to a heat check boar after $3 \mathrm{~d}$ back to the breeding barn. Sows were artificially inseminated twice ( $12 \mathrm{~h}$ apart) after estrus onset. Each insemination was conducted within $18 \mathrm{~h}$ of semen collection (Duroc semen). Pregnancy was detected and confirmed at $\mathrm{d} 30$ post-breeding using an ultrasound scanner (VSS700 EZ Preg Checker, Veterinary Sales \& Service Inc., Stuart, FL, USA). In the gestation building, sows were individually housed in gestation crates $(2.0 \times 0.64 \mathrm{~m})$ with semiautomatic feeders, individual drinkers, and slatted flooring. They were fed $2.2 \mathrm{~kg}$ gestation diet daily which contained $13.3 \%$ crude protein (CP) and 3.3 Mcal metabolizable energy (ME)/kg (Table 1). Water was ad libitum during gestation and lactation. On d 108 of gestation, all of the sows were weighed and moved to farrowing crates $(2.1 \times 1.5 \mathrm{~m})$ in an adjacent farrowing building. Three sows in Exp. 1 and 2 sows in Exp 2. did not maintain their pregnancy and did not farrow. During lactation, sows were fed ad libitum by electronic feeders (JYGA Technologies, Saint-Nicolas, QC, Canada) in the farrowing building. Lactation diet contained $15.8 \% \mathrm{CP}$ and 3.5 

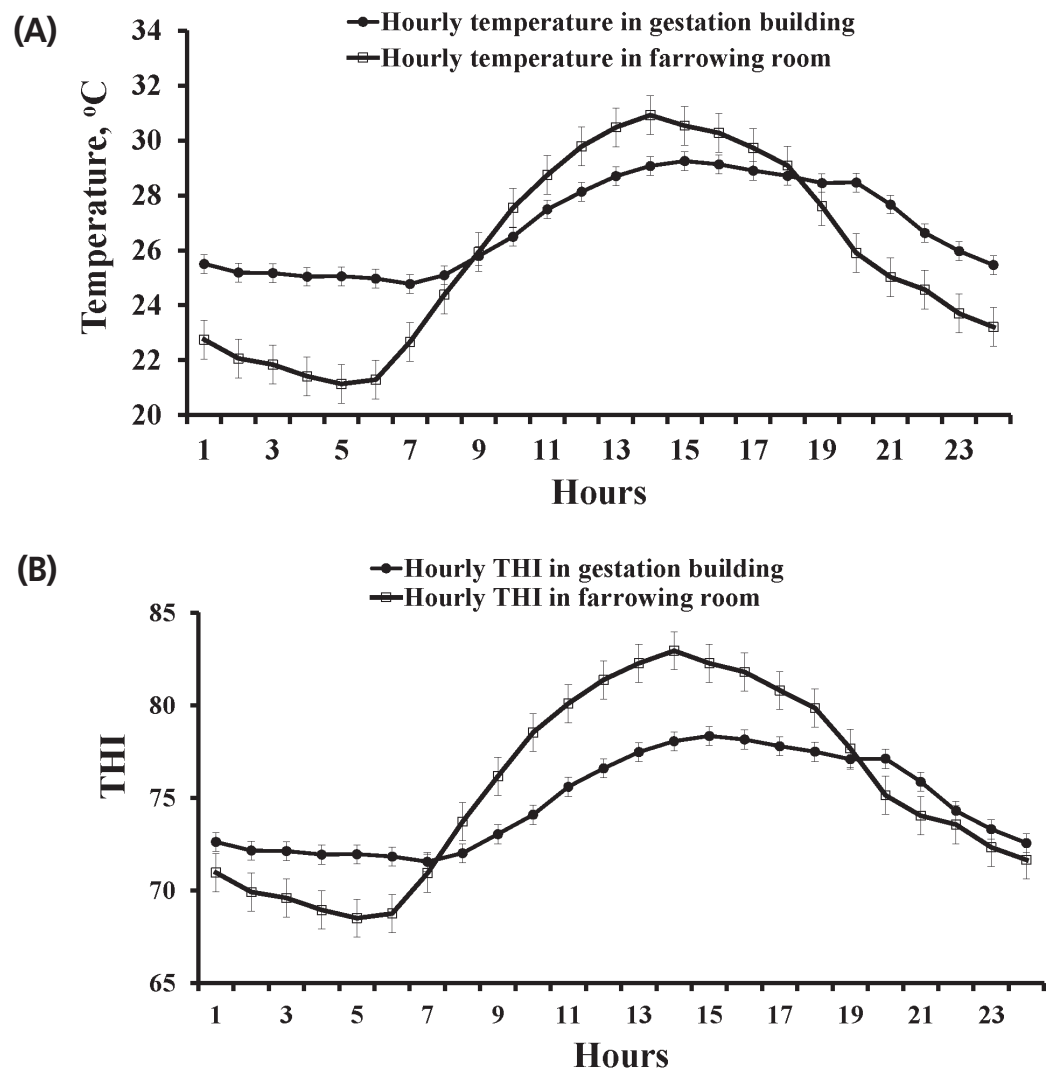

Figure 1. Average hourly temperature (A) and temperature-humidity index (THI) (B) in a day from June to August for sows in a high thermal environment in Exp. 1. Average daily minimum and maximum temperatures of $24.8^{\circ} \mathrm{C} \pm 2.2^{\circ} \mathrm{C}, 30.3^{\circ} \mathrm{C} \pm 2.9^{\circ} \mathrm{C}$ in gestation building, and $22.1^{\circ} \mathrm{C} \pm 1.8^{\circ} \mathrm{C}, 30.9^{\circ} \mathrm{C} \pm 2.6^{\circ} \mathrm{C}$ in farrowing building, respectively.

Mcal ME $/ \mathrm{kg}$ (Table 1). The gestation and lactation diets were formulated to meet or exceed NRC nutrient requirements [15], and formulations were the same in Exp. 1 and 2. In both experiments, any feed left from the previous day was removed and weighed around $0800 \mathrm{~h}$, and the difference between the amount of feed provided and remained was used as an estimate of daily feed intake. The BW of sows was measured on d 35 and 109 of gestation, and d 1 and 18 of lactation. Backfat thickness (10th rib, $6 \mathrm{~cm}$ off-midline) of each sow was measured on $\mathrm{d} 1$ and 18 of lactation using an ultrasound scanner (VSS700 EZ Preg Checker, Veterinary Sales \& Service Inc., USA). After farrowing, individual weight of piglet and litter size of sows on $\mathrm{d} 1$ (total number of piglets, born alive, stillborn, and mummy) and 18 of lactation were measured.

\section{Blood sampling}

In both Exp. 1 and 2, blood was sampled via jugular venipuncture from all of the sows restrained by snout snare between 0900 and $1000 \mathrm{~h}$ on d 35, 60, 90, and 109 of gestation in the gestation building, and $\mathrm{d} 1$ and 18 of lactation in the farrowing building. Blood was collected using $9 \mathrm{~mL}$ ethylenediaminetetraacetic acid-coated syringes and disposable 16-gauge $\times 0.1$-mm hypodermic needles (MONOVETTE,
Sarstedt, Newton, NC, USA; Air-Tite Product Co. Inc., Virginia Beach, VA, USA). Plasma samples were obtained by centrifugation (5810 R, Eppendorf AG, Hamburg, Germany) at $3,000 \mathrm{~g}, 15 \mathrm{~min}, 4^{\circ} \mathrm{C}$, then allocated into $1.5 \mathrm{~mL}$ microcentrifuge tubes, kept in liquid nitrogen for $1 \mathrm{~h}$, and stored at $-80^{\circ} \mathrm{C}$ until analysis.

\section{Analysis of oxidative stress indicators}

Plasma samples from Exp. 1 and 2 were used to measure concentrations of malondialdehyde (MDA), protein carbonyl, and 8-hydroxy-deoxyguanosine (8-OHdG). Concentrations of MDA were measured using the thiobarbituric acid reactive substances assay kit (Cell Biolabs, San Diego, CA, USA) according to the method described by Zhao et al [5]. Plasma samples and MDA standards were incubated and reacted with thiobarbituric acid at $95^{\circ} \mathrm{C}$. After centrifuge and butanol extraction, samples and standards were read at $532 \mathrm{~nm}$ by a spectrophotometric plate reader (Synergy HT, BioTek Instruments, Winooski, VT, USA). Samples were quantified against the standard curve which was constructed by MDA standards. The detective limit of MDA analysis was $0.98 \mu \mathrm{M}$.

Protein concentration in each plasma sample was measured by a bicinchoninic acid protein assay kit (Pierce Biotech- 


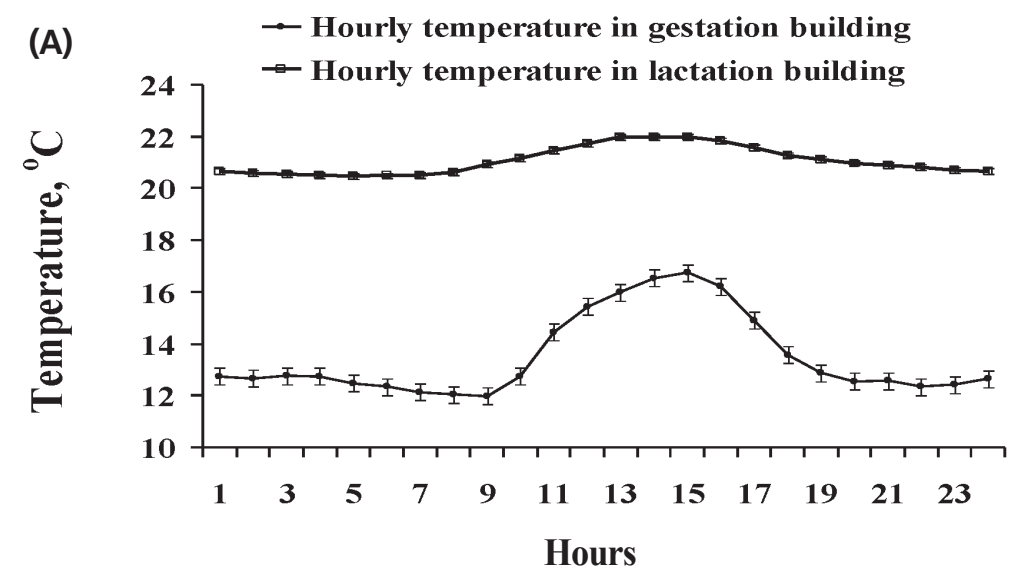

(B)

- Hourly THI in gestation building

$\rightarrow$ Hourly THI in lactation building

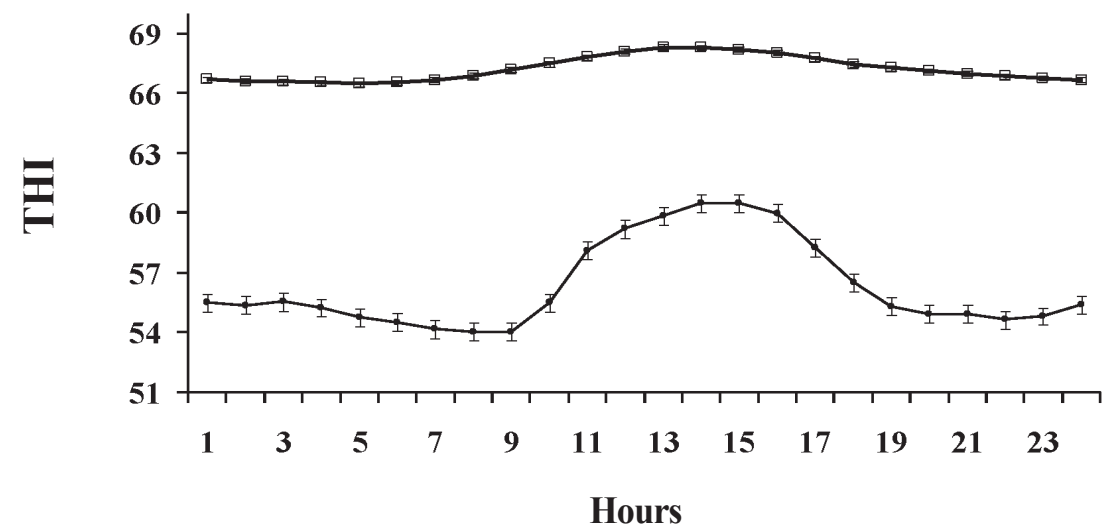

Figure 2. Average hourly temperature $(\mathrm{A})$ and temperature-humidity index (THI) (B) in a day from November to January for sows in a moderate thermal environment in Exp. 2. Average daily minimum and maximum temperatures of $11.9^{\circ} \mathrm{C} \pm 3.0^{\circ} \mathrm{C}, 16.7^{\circ} \mathrm{C} \pm 3.5^{\circ} \mathrm{C}$ in gestation building, and $20.4^{\circ} \mathrm{C} \pm 2.1^{\circ} \mathrm{C}, 22.3^{\circ} \mathrm{C} \pm 2.0^{\circ} \mathrm{C}$ in farrowing building, respectively.

nology, Rockford, IL, USA). Then all plasma samples were diluted with bicinchoninic acid to reach protein concentration at $10 \mu \mathrm{g} / \mathrm{mL}$ before measuring protein carbonyl. Protein carbonyl concentration in each diluted plasma sample was measured via the protein carbonyl ELISA kit (Cell Biolabs, USA) according to the method described by Shen et al [16]. The protein carbonyl presented in the sample or standard was first derivatized to dinitrophenyl hydrazine and probed with an anti-dinitrophenyl antibody, then incubated with a secondary antibody. Finally substrates and stop solutions were added. Standards and samples were read at $450 \mathrm{~nm}$ by a spectrophotometric plate reader (Synergy HT, BioTek Instruments, USA). Protein carbonyl concentrations in samples were quantified against the standard curve which was drawn by protein carbonyl standards. The detective limit for protein carbonyl was $0.375 \mathrm{nmol} / \mathrm{mg}$.

Concentrations of 8-OHdG in plasma samples were measured using the oxidative DNA damage enzyme-linked immunosorbent assay (ELISA) kit (Cell Biolabs, USA) according to the method described by Weaver and Kim [17]. Briefly, plas- ma samples and 8-OHdG standards were first added into a 96-well plate. Then an anti-8-OHdG monoclonal antibody was added, followed by adding a secondary antibody. A substrate solution and stop solution were added. The absorbance of each well was read at $450 \mathrm{~nm}$ by a spectrophotometric plate reader (Synergy HT, BioTek Instruments, USA). Concentrations of 8-OHdG in plasma samples were quantified against the standard curve which was constructed by $8-\mathrm{OHdG}$ standards. The detective limit for $8-\mathrm{OHdG}$ was $0.078 \mathrm{ng} / \mathrm{mL}$.

\section{Immunoglobulin evaluation}

In both experiments, concentrations of immunoglobulin $\mathrm{G}$ (IgG) and IgM in sows' plasma on d 109 of gestation, $\mathrm{d} 1$ and 18 of lactation were measured by ELISA kits (Bethyl, Montgomery, TX, USA) according to the method described by Chaytor et al [18]. Briefly, goat anti-pig IgG or IgM were used as capture antibodies to coat wells. All of the samples were diluted to $1: 100,000$ for IgG and IgM measurement. Horseradish peroxidase goat anti-pig IgG or IgM was used as the detection. The plate was read at $450 \mathrm{~nm}$ by an ELISA plate 
Table 1. Composition of gestation and lactation diets (as-fed basis) in Exp. 1 and 2

\begin{tabular}{lcc}
\hline Item & Gestation & Lactation \\
\hline Ingredient & & \\
Corn, yellow (\%) & 81.30 & 74.00 \\
Soybean meal, 48\% CP (\%) & 13.85 & 19.60 \\
Poultry fat (\%) & 1.00 & 3.99 \\
L-Lys (\%) & 0.00 & 0.25 \\
L-Thr (\%) & 0.00 & 0.01 \\
Limestone (\%) & 1.11 & 1.08 \\
Dicalcium phosphate (\%) & 2.05 & 2.38 \\
Salt (\%) & 0.50 & 0.50 \\
Trace mineral permix) (\%) & 0.15 & 0.15 \\
Vitamin permix (\%) & 0.04 & 0.04 \\
Total & 100.00 & 100.00 \\
Calculated composition & & \\
DM (\%) & 89.7 & 90.1 \\
ME (Mcal/kg) & 3.3 & 3.5 \\
CP (\%) & 13.3 & 15.8 \\
Lys (\%) & 0.63 & 0.92 \\
Met (\%) & 0.49 & 0.51 \\
Trp (\%) & 0.14 & 0.17 \\
Thr (\%) & 0.49 & 0.55 \\
Ca (\%) & 1.03 & 1.12 \\
Total P (\%) & 0.69 & 0.76 \\
\hline CP $\%$ ( $\%$ proten;DM &
\end{tabular}

$\mathrm{CP}$, crude protein; $\mathrm{DM}$, dry matter; $\mathrm{ME}$, metabolizable energy.

1) The trace mineral premix provided per kilogram of complete diet: $3.96 \mathrm{mg}$ of $\mathrm{Mn}$ as manganous oxide; $16.5 \mathrm{mg}$ of Fe as ferrous sulfate; $16.5 \mathrm{mg}$ of $\mathrm{Zn}$ as zinc sulfate; $1.65 \mathrm{mg}$ of Cu as copper sulfate; $0.30 \mathrm{mg}$ of I as ethylenediamine dihydroiodide; and $0.30 \mathrm{mg}$ of Se as sodium selenite.

${ }^{2)}$ The vitamin premix provided per kilogram of complete diet: 8,228 IU of vitamin $A$ as vitamin A acetate; 1,173 IU of vitamin $D_{3} ; 47$ IU of vitamin $E ; 0.03 \mathrm{mg}$ of vitamin $\mathrm{B}_{12} ; 5.88 \mathrm{mg}$ of riboflavin; $23.52 \mathrm{mg}$ of $\mathrm{D}$-pantothenic acid as calcium panthonate; $35.27 \mathrm{mg}$ of niacin; $0.24 \mathrm{mg}$ of biotin; $1.76 \mathrm{mg}$ folic acid; $3.88 \mathrm{mg}$ menadione. reader (Synergy HT, BioTek Instruments, USA) and software (KC4 Data Analysis Software, BioTek Tnstrument, USA). Sample concentration was quantified against the standard curve which was drawn by standards. Detective limits were $7.8 \mathrm{ng} / \mathrm{mL}$ for $\mathrm{IgG}$, and $15.6 \mathrm{ng} / \mathrm{mL}$ for IgM, respectively.

\section{Statistical analysis}

Exp. 1 and 2 were completely randomized designs. Data from oxidative stress indicators and immunoglobulin assay were compared among different gestation and lactation days in both experiments using the MIXED procedure of SAS (SAS Inst. Inc., Cary, NC, USA). Oxidative stress data from d 35 of gestation was used as a covariance when analyzing the oxidative stress indicators. The individual sow was the experimental unit. Day was a fixed effect and the sow was a random effect. The canonical correlation between reproductive performance and oxidative stress indicators on different days in Exp. 1 and 2 were analyzed by the CANCORR procedure of SAS (SAS Inst., Inc., USA), respectively. Data was considered statistically different when probability values were less than 0.05 , and probability less than 0.1 and equal or greater than 0.05 was considered as a trend.

\section{RESULTS}

\section{Oxidative stress parameters}

Plasma concentrations of MDA, protein carbonyl, and 8-OHdG were compared among days during gestation and lactation in Exp. 1 and 2, respectively (Table 2). For sows in Exp. 1, plasma MDA concentration on d 109 of gestation tended to be greater $(\mathrm{p}=0.096)$ than it on $\mathrm{d} 18$ of lactation (Table 2$)$.

Table 2. Oxidative stress indicators of sows under a high thermal environment $(H T)^{1)}$ in Exp. 1 and a moderate thermal environment (MT) $)^{1)}$ in Exp. 2

\begin{tabular}{|c|c|c|c|c|c|c|c|c|}
\hline \multirow{2}{*}{ Item } & \multicolumn{4}{|c|}{ Gestation } & \multicolumn{2}{|c|}{ Lactation } & \multirow{2}{*}{ SEM } & \multirow{2}{*}{$p$-value } \\
\hline & d $35^{2)}$ & $\mathrm{d} 60$ & d 90 & d 109 & d 1 & d 18 & & \\
\hline \multicolumn{9}{|l|}{ Exp. 1} \\
\hline Malondialdehyde ( $\mu \mathrm{M})$ & 6.14 & $6.39^{A B}$ & $7.51^{\mathrm{AB}}$ & $8.54^{A}$ & $8.39^{\mathrm{AB}}$ & $6.02^{B}$ & 1.05 & 0.096 \\
\hline Protein carbonyl (nmol/mg) & 1.41 & $1.00^{\mathrm{a}}$ & $1.06^{\mathrm{a}}$ & $2.29^{c}$ & $1.40^{\mathrm{ab}}$ & $1.76^{\mathrm{b}}$ & 0.13 & $<0.001$ \\
\hline 8-hydroxy-deoxyguanosine (ng/mL) & 0.32 & $0.59^{\mathrm{ab}}$ & $0.61^{a b}$ & $0.95^{b}$ & $0.62^{\mathrm{ab}}$ & $0.29^{\mathrm{a}}$ & 0.12 & 0.006 \\
\hline \multicolumn{9}{|l|}{ Exp. 2} \\
\hline$n^{3)}$ & 12 & 12 & 12 & 12 & 12 & 12 & & \\
\hline Malondialdehyde $(\mu \mathrm{M})$ & 4.42 & 4.63 & 4.00 & 2.56 & 3.53 & 5.26 & 0.98 & 0.285 \\
\hline Protein carbonyl (nmol/mg) & 1.59 & 1.50 & 0.72 & 1.03 & 1.29 & 0.76 & 0.22 & 0.122 \\
\hline 8-hydroxy-deoxyguanosine (ng/mL) & 0.71 & $1.00^{b}$ & $0.90^{b}$ & $1.07^{b}$ & $1.04^{b}$ & $0.48^{\mathrm{a}}$ & 0.12 & $<0.001$ \\
\hline
\end{tabular}

SEM, standard error of the mean.

1) $\mathrm{HT}$, high thermal environment (average daily minimum and maximum temperatures of $24.8^{\circ} \mathrm{C} \pm 2.2^{\circ} \mathrm{C}, 30.3^{\circ} \mathrm{C} \pm 2.9^{\circ} \mathrm{C}$ in gestation building, and $22.1^{\circ} \mathrm{C} \pm 1.8^{\circ} \mathrm{C}$,

$30.9^{\circ} \mathrm{C} \pm 2.6^{\circ} \mathrm{C}$ in farrowing building, respectively); $\mathrm{MT}$, moderate thermal environment (average daily minimum and maximum temperatures of $11.9^{\circ} \mathrm{C} \pm 3.0^{\circ} \mathrm{C}$,

$16.7^{\circ} \mathrm{C} \pm 3.5^{\circ} \mathrm{C}$ in gestation building, and $20.4^{\circ} \mathrm{C} \pm 2.1^{\circ} \mathrm{C}, 22.3^{\circ} \mathrm{C} \pm 2.0^{\circ} \mathrm{C}$ in farrowing building, respectively).

${ }^{2)}$ Oxidative stress data from $\mathrm{d} 35$ of gestation was used as a covariance when analyzing the oxidative stress indicators.

${ }^{3)}$ Initial number of sows was 14. There were 3 sows in Exp. 1 and 2 sows in Exp. 2 did not maintain pregnancy and did not farrow which were excluded from the study.

${ }^{a-c}$ Means within a row with different superscripts differ $(p<0.05)$.

$A, B$ Means within a row tend to differ $(0.05 \leq p<0.10)$. 
Plasma concentration of protein carbonyl on d 109 of gestation was the greatest $(\mathrm{p}<0.05)$ compared with all the other days (Table 2). Besides, protein carbonyl concentration on $\mathrm{d}$ 18 of lactation was greater $(\mathrm{p}<0.05)$ than concentrations on d 60 and 90 of gestation. Plasma concentrations of 8-OHdG on $\mathrm{d} 109$ of gestation was greater $(\mathrm{p}<0.05)$ than $\mathrm{d} 18$ of lactation in Exp. 1 (Table 2). For sows in Exp. 2, there was no difference of MDA concentration among gestation and lactation days (Table 2). Protein carbonyl concentration did not differ among days (Table 2). However, plasma concentration of 8 -OHdG on $\mathrm{d} 18$ of lactation was smaller $(\mathrm{p}<0.05)$ than all the other days in Exp. 2 (Table 2).

\section{Reproductive performance of sows}

In Exp. 1, sows gained $35.0 \mathrm{~kg}$ from d 35 to 109 of gestation, but lost $1.5 \mathrm{~kg}$ from d 1 to 18 of lactation. Sows consumed $4.3 \pm 1.1 \mathrm{~kg}$ feed daily during lactation. Sows had $9.5 \pm 2.9$ pigs born alive per litter, and weaned $7.4 \pm 2.1$ pigs per litter at the end of lactation. Litters gained $27.1 \pm 8.7 \mathrm{~kg}$ from d 1 to 18 of lactation. Piglets gained $204.4 \pm 41.3 \mathrm{~g}$ daily during lactation (Table 3).

In Exp. 2, sows gained $46.6 \mathrm{~kg}$ from d 35 to 109 of gestation, but lost $14.7 \mathrm{~kg}$ from $\mathrm{d} 1$ to 18 of lactation. Sows consumed $4.6 \pm 1.1 \mathrm{~kg}$ feed daily during lactation. Sows had $11.9 \pm 1.8$ pigs born alive per litter, and weaned $10.4 \pm 1.2$ pigs per litter at the end of lactation. Litters gained $37.5 \pm 9.5 \mathrm{~kg}$ from $\mathrm{d} 1$ to 18 of lactation. Piglets gained $199.5 \pm 41.2 \mathrm{~g}$ daily during lactation (Table 3).

\section{Immunoglobulin evaluation}

Plasma concentrations of IgG and IgM were compared among d 109 of gestation, and d 1 and 18 of lactation in Exp. 1 and 2, respectively (Table 4). For sows in Exp. 1, there was no difference for plasma concentrations of IgG and IgM on d 109 of gestation, and $\mathrm{d} 1$ and 18 of lactation (Table 4). For sows in Exp. 2, plasma concentration of IgM did not differ among different days. However, plasma concentration of IgG on $\mathrm{d}$ 18 of lactation was greater $(\mathrm{p}<0.05)$ than it on $\mathrm{d} 1$ of lactation (Table 4).

Canonical correlation analysis between oxidative stress and reproductive performance

Three sets of canonical relationships between oxidative stress indicators and reproductive performance of sows were obtained in Exp. 1 (Table 5). The first set of variables are oxidative stress indicators including concentrations of MDA, protein carbonyl, and 8-OHdG on d 60 and 90 of gestation, and d18 of lactation $\left(M_{\mathrm{d} 60}, P_{\mathrm{d} 60}, O_{\mathrm{d} 60}, M_{\mathrm{d} 90}, P_{\mathrm{d} 90}, O_{\mathrm{d} 90}, M_{\mathrm{d} 18}, P_{\mathrm{d} 18}\right.$, and $\left.O_{\mathrm{d} 18}\right)$. The second set of variables are $\mathrm{BW}$ and backfat of sows, and piglet weight on $\mathrm{d} 3$ and 18 of lactation $\left(X_{1}, X_{2}, X_{3}, X_{4}\right.$, $X_{5}$, and $\left.X_{6}\right)$. The correlation coefficients in the first set of canonical relationship reached a significant level $(\mathrm{p}<0.05)$, and
Table 3. Reproductive performance of sows under a high thermal environment $(\mathrm{HT})^{1)}$ in Exp. 1 and a moderate thermal environment (MT) ${ }^{1)}$ in Exp. 2

\begin{tabular}{|c|c|c|c|c|}
\hline Item & Exp. 1 & $\mathrm{SD}^{2)}$ & Exp. 2 & $\mathrm{SD}^{2)}$ \\
\hline$n^{3)}$ & 11 & & 12 & \\
\hline Parity & 5.8 & 3.2 & 5.1 & 1.3 \\
\hline \multicolumn{5}{|l|}{ Body weight of sows (kg) } \\
\hline d 35 of gestation & 246 & 39 & 243 & 30 \\
\hline d 109 of gestation & 281 & 35 & 290 & 27 \\
\hline d 1 of lactation & 275 & 32 & 276 & 28 \\
\hline d 18 of lactation & 273 & 29 & 261 & 31 \\
\hline \multicolumn{5}{|l|}{ Body weight changes (kg) } \\
\hline Gestation (d 35 to 109) & 35 & 17 & 47 & 14 \\
\hline Lactation (d 1 to 18) & -5 & 13 & -13 & 17 \\
\hline \multicolumn{5}{|l|}{ Backfat of sows ${ }^{4)}(\mathrm{mm})$} \\
\hline d 1 of lactation & 17.0 & 2.5 & 15.8 & 3.9 \\
\hline d 18 of lactation & 16.6 & 2.9 & 14.4 & 3.8 \\
\hline Change from d 1 to $18^{5)}$ & -0.4 & 2.7 & -1.4 & 1.6 \\
\hline ADFI of sows (kg) & 4.3 & 1.1 & 4.6 & 1.1 \\
\hline \multicolumn{5}{|l|}{ Litter size (pig) } \\
\hline d 1, total born & 12.5 & 2.9 & 13.6 & 2.2 \\
\hline d 1, born alive & 9.5 & 2.9 & 11.9 & 1.8 \\
\hline d 1, stillborn & 2.5 & 1.9 & 1.2 & 1.2 \\
\hline d 1, mummy & 0.5 & 0.8 & 0.4 & 0.9 \\
\hline d 18 & 7.4 & 2.1 & 10.4 & 1.2 \\
\hline Change from d 1 to $18^{5)}$ & -2.2 & 1.7 & -1.5 & 1.7 \\
\hline \multicolumn{5}{|l|}{ Litter weight $(\mathrm{kg})$} \\
\hline$d 1^{6)}$ & 15.0 & 3.7 & 17.9 & 2.9 \\
\hline d 18 & 42.1 & 11.7 & 55.4 & 11.2 \\
\hline Gain from d 1 to $18^{5)}$ & 27.1 & 8.7 & 37.5 & 9.5 \\
\hline \multicolumn{5}{|l|}{ Piglet weight (kg) } \\
\hline$d 1^{7)}$ & 1.66 & 0.42 & 1.52 & 0.20 \\
\hline d 18 & 5.78 & 0.96 & 5.42 & 0.78 \\
\hline ADG from $d 1$ to $18(\mathrm{~g} / \mathrm{d})$ & 204 & 41 & 200 & 41 \\
\hline
\end{tabular}

$S D$, standard deviation; $A D F I$, average daily feed intake; $A D G$, average daily gain.

${ }^{1)} \mathrm{HT}$, high thermal environment (average daily minimum and maximum temperatures of $24.8^{\circ} \mathrm{C} \pm 2.2^{\circ} \mathrm{C}, 30.3^{\circ} \mathrm{C} \pm 2.9^{\circ} \mathrm{C}$ in gestation building, and $22.1^{\circ} \mathrm{C} \pm 1.8^{\circ} \mathrm{C}, 30.9^{\circ} \mathrm{C} \pm 2.6^{\circ} \mathrm{C}$ in farrowing building, respectively); MT, moderate thermal environment (average daily minimum and maximum temperatures of $11.9^{\circ} \mathrm{C} \pm 3.0^{\circ} \mathrm{C}, 16.7^{\circ} \mathrm{C} \pm 3.5^{\circ} \mathrm{C}$ in gestation building, and $20.4^{\circ} \mathrm{C} \pm 2.1^{\circ} \mathrm{C}$, $22.3^{\circ} \mathrm{C} \pm 2.0^{\circ} \mathrm{C}$ in farrowing building, respectively).

${ }^{2)}$ Results are expressed as mean with SD.

${ }^{3)}$ Initial number of sows was 14 for both Exp. 1 and 2. There were 3 sows in Exp. and 2 sows in Exp. 2 did not maintain pregnancy and did not farrow which were excluded from the study.

${ }^{4)}$ Measured at the $P 2$ position (locate at left side of the 10 th rib, and $6 \mathrm{~cm}$ away from the spine).

5) Difference between $d 1$ and 18 of lactation

${ }^{6)}$ Litter weight at birth includes piglets born alive only.

${ }^{7)}$ Weight of piglets born alive.

the other two sets showed tendency ( $p=0.093$ and 0.059 ), suggesting that there is a significant canonical correlation between oxidative stress and reproductive performance of sow in Exp. 1 (Table 5). From the linear expression of canonical variable composition in the first set of canonical relationship, $M_{\mathrm{d} 60}, O_{\mathrm{d} 60}$, and $X_{2}$ were relatively large (Table 5), showing that plasma concentration of MDA and 8-OHdG on d 60 of ges- 
Table 4. Immunological parameters of sows under a high thermal environment $(H T)^{11}$ in Exp. 1 and a moderate thermal environment (MT) ${ }^{11}$ in Exp. 2

\begin{tabular}{|c|c|c|c|c|c|}
\hline \multirow[b]{2}{*}{ Item } & \multicolumn{3}{|c|}{ Plasma } & \multirow[b]{2}{*}{ SEM } & \multirow[b]{2}{*}{$p$ value } \\
\hline & $\begin{array}{l}\text { d } 109 \text { of } \\
\text { gestation }\end{array}$ & $\begin{array}{l}\text { d } 1 \text { of } \\
\text { lactation }\end{array}$ & $\begin{array}{l}\mathrm{d} 18 \text { of } \\
\text { lactation }\end{array}$ & & \\
\hline \multicolumn{6}{|l|}{ Exp. 1} \\
\hline$n^{2)}$ & 11 & 11 & 11 & - & - \\
\hline $\operatorname{lgM}(\mathrm{mg} / \mathrm{mL})$ & 3.25 & 2.55 & 2.33 & 0.41 & 0.419 \\
\hline $\lg \mathrm{g}(\mathrm{mg} / \mathrm{mL})$ & 19.38 & 17.98 & 19.67 & 1.69 & 0.898 \\
\hline \multicolumn{6}{|l|}{ Exp. 2} \\
\hline$n^{2)}$ & 12 & 12 & 12 & - & - \\
\hline $\operatorname{lgM}(\mathrm{mg} / \mathrm{mL})$ & 2.96 & 2.36 & 2.53 & 0.28 & 0.621 \\
\hline $\operatorname{lgG}(\mathrm{mg} / \mathrm{mL})$ & $19.20^{\mathrm{ab}}$ & $16.22^{\mathrm{a}}$ & $20.07^{b}$ & 1.19 & 0.031 \\
\hline
\end{tabular}

SEM, standard error of the mean; IgM, immunoglobulin $\mathrm{M}$; IgG, immunoglobulin G.

${ }^{1)} \mathrm{HT}$, high thermal environment (average daily minimum and maximum temperatures of $24.8^{\circ} \mathrm{C} \pm 2.2^{\circ} \mathrm{C}, 30.3^{\circ} \mathrm{C} \pm 2.9^{\circ} \mathrm{C}$ in gestation building, and $22.1^{\circ} \mathrm{C} \pm 1.8^{\circ} \mathrm{C}, 30.9^{\circ} \mathrm{C} \pm 2.6^{\circ} \mathrm{C}$ in farrowing building, respectively); MT, moderate thermal environment (average daily minimum and maximum temperatures of $11.9^{\circ} \mathrm{C} \pm 3.0^{\circ} \mathrm{C}, 16.7^{\circ} \mathrm{C} \pm 3.5^{\circ} \mathrm{C}$ in gestation building, and $20.4^{\circ} \mathrm{C} \pm 2.1^{\circ} \mathrm{C}$, $22.3^{\circ} \mathrm{C} \pm 2.0^{\circ} \mathrm{C}$ in farrowing building, respectively).

${ }^{2)}$ Initial number of sows was 14. There were 3 sows in Exp. 1 and 2 sows in Exp.

2 did not maintain pregnancy and did not farrow which were excluded from the study.

$a, b$ Means within a row with different superscripts differ $(p<0.05)$.

tation are negatively correlated with BW of sows on d 18 of lactation. As can be seen from the linear expression of canonical variables in the second set of canonical relationship, $M_{\mathrm{d} 00}$, $P_{\mathrm{d} 90}$, and $X_{4}$ were relatively large (Table 5 ), showing that plasma concentration of MDA and protein carbonyl on d 90 of gestation are negatively correlated with backfat of sows on d 18 of lactation. In the third set of canonical relationship, there was a large load on $M_{\mathrm{d} 18}, P_{\mathrm{d} 18}$, and $X_{6}$ (Table 5), suggesting that plasma concentration of MDA and protein carbonyl on d 18 of lactation are negatively correlated with piglet weight on $\mathrm{d} 18$ of lactation.

Two sets of canonical relationships between oxidative stress indicators and reproductive performance of sows in Exp. 2 and the composition of canonical variables are shown in Table 6. The first set of variables are oxidative stress indicators including concentrations of MDA, protein carbonyl, and 8-OHdG on d 90 of gestation, and $\mathrm{d} 3$ of lactation $\left(M_{\mathrm{d} 90}\right.$, $P_{\mathrm{d} 90}, O_{\mathrm{d} 90}, M_{\mathrm{d} 3}, P_{\mathrm{d} 3}$, and $\left.O_{\mathrm{d} 3}\right)$. The second set of variables are piglet weight on $\mathrm{d} 3$ and 18 of lactation, litter size of born alive and wean of sows $\left(X_{5}, X_{6}, X_{7}\right.$, and $\left.X_{8}\right)$. The correlation coefficients in the first and second set of canonical relationships reached a significant level $(\mathrm{p}<0.05)$, suggesting that there is a significant canonical correlation between oxidative stress and reproductive performance of sow in Exp. 2 (Table 6). From the linear expression of canonical variable composition in the first set of canonical relationship, $M_{\mathrm{d} 3}$, $O_{\mathrm{d} 3}$, and $X_{6}$ were relatively large (Table 6), showing that MDA and $8-\mathrm{OHdG}$ on $\mathrm{d} 3$ of lactation are negatively correlated with piglet weight on $\mathrm{d} 18$ of lactation. As can be seen from the linear expression of canonical variables in the second set of canonical relationship, there was a large load on $P_{\mathrm{d} 90}$ and $X_{8}$ (Table 6), suggesting that protein carbonyl on $\mathrm{d} 90$

Table 5. Canonical correlations between oxidative stress indicators and reproductive performance of sows in Exp. 1

\begin{tabular}{lcccc}
\hline The first set of variables ${ }^{1)}$ & $\begin{array}{c}\text { The second set of } \\
\text { variables }^{2)}\end{array}$ & $\begin{array}{c}\text { Canonical correlation } \\
\text { coefficient }\end{array}$ & p-value & Canonical variable composition \\
\hline Oxidative stress indicators & Sow BW & 0.990 & 0.023 & $\begin{array}{l}V_{1}=0.924 M_{\mathrm{d} 60}+0.340 P_{\mathrm{d} 60}+0.652 O_{\mathrm{d} 60} \\
W_{1}=0.364 X_{1}-1.222 X_{2}\end{array}$ \\
Oxidative stress indicators & Sow backfat & 0.879 & 0.093 & $\begin{array}{l}V_{1}=1.211 M_{\mathrm{d} 90}+1.143 P_{\mathrm{d} 90}+0.6210_{\mathrm{d} 90} \\
W_{1}=0.277 X_{3}-1.026 X_{4}\end{array}$ \\
Oxidative stress indicators & Piglet weight & 0.960 & 0.059 & $\begin{array}{l}V_{1}=-0.988 M_{\mathrm{d} 18}-1.448 P_{\mathrm{d} 18}-0.4130_{\mathrm{d} 18} \\
W_{1}=0.269 X_{5}+0.821 X_{6}\end{array}$ \\
\hline
\end{tabular}

BW, body weight.

1) The first set of variables are oxidative stress indicators including concentrations of malondialdehyde, protein carbonyl, and 8-hydroxy-deoxyguanosine on d 60 and 90 of gestation, and d18 of lactation $\left(M_{\mathrm{d} 60,}, P_{\mathrm{d} 60,}, O_{\mathrm{d} 60,}, M_{\mathrm{d} 90,}, P_{\mathrm{d} 90,} O_{\mathrm{d} 90,}, M_{\mathrm{d} 18,}, P_{\mathrm{d} 18,}\right.$ and $\left.O_{\mathrm{d} 18}\right)$.

${ }^{2)}$ The second set of variables are BW and backfat of sows, and piglet weight on $\mathrm{d} 3$ and 18 of lactation $\left(X_{1}, X_{2}, X_{3}, X_{4}, X_{5}\right.$, and $\left.X_{6}\right)$.

Table 6. Canonical correlations between oxidative stress indicators and reproductive performance of sows in Exp. 2

\begin{tabular}{lcccc}
\hline The first set of variables $^{1)}$ & $\begin{array}{c}\text { The second set of } \\
\text { variables }\end{array}$ & $\begin{array}{c}\text { Canonical correlation } \\
\text { coefficient }\end{array}$ & p-value & Canonical variable composition \\
\hline Oxidative stress indicators & Piglet weight & 0.999 & 0.024 & $\begin{array}{l}V_{1}=0.482 M_{\mathrm{d} 3}-0.215 P_{\mathrm{d} 3}+0.8230_{\mathrm{d} 3} \\
W_{1}=-0.187 X_{5}-0.986 X_{6}\end{array}$ \\
Oxidative stress indicators & Sow litter size & 0.999 & 0.023 & $\begin{array}{l}V_{1}=0.181 M_{\mathrm{d} 90}-1.029 P_{\mathrm{d} 90}+0.0770_{\mathrm{d} 90} \\
W_{1}=0.257 X_{7}+0.889 X_{8}\end{array}$ \\
\hline
\end{tabular}

\footnotetext{
${ }^{1)}$ The first set of variables are oxidative stress indicators including concentrations of malondialdehyde, protein carbonyl, and 8-hydroxy-deoxyguanosine on $\mathrm{d} 90$ of gestation, and $\mathrm{d} 3$ of lactation $\left(M_{\mathrm{d} 90,}, P_{\mathrm{d} 90,} O_{\mathrm{d} 90,}, M_{\mathrm{d} 33}, P_{\mathrm{d} 3}\right.$ and $\left.O_{\mathrm{d} 3}\right)$.

${ }^{2)}$ The second set of variables are piglet weight on $\mathrm{d} 3$ and 18 of lactation, and litter size of born alive and wean of sows $\left(X_{5}, X_{6}, X_{7}\right.$, and $\left.X_{8}\right)$.
} 
of gestation is negatively correlated with litter size of sows on 18 of lactation.

\section{DISCUSSION}

In this study we have confirmed that sows under a high thermal environment had increased oxidative stress during late gestation, and the increased oxidative damage to lipid, protein, and DNA could be one of the contributing factors for reduced reproductive performance of sows under the high thermal environment. Hence, we accepted the hypothesis that oxidative stress status of sows could elevate during late gestation and lactation when sows are housed under high thermal environment, and the elevated oxidative stress could be detrimental to the reproductive performance of sows.

In this study, sows in Exp. 1 were under heat stress condition indicated by the observed ambient temperatures and THI. We observed that the ambient temperature in Exp. 1 were above $25^{\circ} \mathrm{C}$ for an average of $17 \mathrm{~h} / \mathrm{d}$ in the gestation building and $14 \mathrm{~h} / \mathrm{d}$ in the farrowing building. Environmental temperature remaining above $25^{\circ} \mathrm{C}$ could cause heat stress to sows [19]. Meanwhile, high levels of THI (72 to 78 in the gestation building, and 69 to 83 in the farrowing building) was also observed in Exp. 1. The THI is a combination of temperature and humidity which has been used to indicate heat stress environment. It was reported that the THI value less than 74 was classified as a safe, whereas critical when greater than 74 in sows [20]. The observed high THI in Exp. 1 can be detrimental to sows, because the high temperature and high humidity together can limit their heat loss through evaporation [21]. These data indicated that sows in Exp. 1 were under heat stress condition. On the other hand, based on the average daily maximum and minimum temperatures and THI recorded in Exp. 2, it seems that sows in Exp. 2 were kept within their thermos-neutral environment.

Our Exp. 1 was conducted from June to August in North Carolina, which we observed the reduced reproductive performance of sows indicated by the less number of total born, born alive, more still born piglets, and small litter size and litter weight gain. These results indicated that the reproductive performance of sows in Exp. 1 was negatively affected by the heat stress environment. The smaller litter size of sow in Exp. 1 contributed to reduce mobilizing of their body reserve for less milk production, which may explain why sows in Exp. 1 lost less BW and backfat during lactation compared with sows in Exp. 2. Similar result was reported that the over-all reproductive performance of sows reduced in large confinement units in North Carolina during hot months from June to October [22].These findings were also consistent with other studies which showed that sows under high thermal environment during gestation farrowed fewer born alive with increased number of stillborn [8]. On the other hand, feed intake of lactating sows was not the main factor for the reduced milk production in Exp.1. Because feed intake in Exp. 1 was similar to that in Exp. 2, and it did not show significant reduction as some other studies have found [23]. This may be because it took a few days for sows to adjust the electronic feeders in the farrowing room.

Besides the reduced reproductive performance of sows in Exp. 1, heat stress environment also affected the oxidative stress status of sows indicated by the enhanced oxidative damage to lipid, protein, and DNA during late gestation. The plasma MDA, protein carbonyl, and 8-OHdG concentration increased during late gestation which showing that sows could suffer severe oxidative damage during late gestation under heat stress environment. The current results indicate that oxidative stress could be one of stress responses caused by high thermal environment. On the other hand, sow in Exp. 2 did not show the similar pattern with Exp. 1. Although sows had increased oxidative DNA damage during gestation and early lactation compared with late lactation, other oxidative indicators for protein and lipid did not enhanced, indicating that sows in Exp. 2 did not suffer severe oxidative stress during gestation and lactation when they were housed under moderate thermal environment. Previous studies showed that sows were under severe catabolic status during late gestation and lactation which could induce oxidative damage and decrease antioxidants concentration at the same period [12-14]. Studies also found that the ROS production increased under the high temperature treatment [24,25], which could explain why sows in Exp. 1 showed enhanced oxidative stress. However, the molecular mechanisms responsible for excessive ROS production or lowered antioxidant defenses under heat stress are still not known in sows. There are some reports in poultry which found that heat stressed chickens exhibit overproduction of mitochondrial ROS in skeletal muscle, which might result from enhanced substrate oxidation and downregulation of avian uncoupling protein [26,27].

As discussed above, heat stress environment negatively affected the reproductive performance and enhanced the oxidative damage to sows during late gestation and lactation. We hypothesized that the elevated oxidative stress could be detrimental to the reproductive performance of sows. Therefore, we investigated the relationship between oxidative stress indicators and reproductive performance of sows during gestation and lactation under both moderate and high thermal environments. The canonical correlation coefficients were close to 1 for all the sets of canonical relationships, and the linear expression of canonical variable compositions showed that there were negative correlations between oxidative stress indicators and piglet weight, BW, backfat, and litter size of sows in current studies. These results indicates a strong correlation between oxidative stress indicators and reproductive 
performance of sows. Similar results were reported in previous study, which showed that oxidative damages to lipid, protein, and DNA were negatively correlated with reproductive performance of gestating sows under social stress [5]. Excessive ROS could negatively affect multiple physiological processes from oocyte maturation to fertilization, embryo development and pregnancy [28]. Study on pregnant women showed that oxidative stress can increase membrane damage which is related with fetal growth retardation and cause a higher risk of prenatal mortality [29].

In Exp. 1, plasma concentrations of IgG and IgM were not different among days, indicating that sows did not suffer immune challenge during the study. The plasma concentration of IgG on $\mathrm{d} 1$ of lactation in Exp. 2 was smaller than it on $\mathrm{d} 18$ of lactation, but both of them were within the normal range [30]. The decreased plasma concentration of IgG on $\mathrm{d} 1$ of lactation may be because more IgG in the blood were secreted into the colostrum.

\section{CONCLUSION}

Taken together, sows under a high thermal environment had increased oxidative stress during late gestation. These oxidative stress indicators were negatively correlated with reproductive performance of sows, suggesting that increased oxidative damage to lipid, protein, and DNA could be one of the contributing factors for reduced reproductive performance of sows under the high thermal environment. This study indicates the importance of providing a moderate thermal environment to gestating and lactating sows to minimize the increase of oxidative stress during late gestation which can impair reproductive outcomes. Our findings in this study also shows the importance for future studies to regulate oxidative stress status of sow during gestation and lactation under heat stress.

\section{CONFLICT OF INTEREST}

We certify that there is no conflict of interest with any financial organization regarding the material discussed in the manuscript.

\section{ACKNOWLEDGEMENTS}

This study was supported by grants from North Carolina Pork Council (10M69MF1), Shanxi Agriculture University Science \& Technology Innovation Fund (2017YJ07), and Key Projects of Shanxi Key R\&D Program (201703D211001). The authors wish to thank Dr. Alysson Saraiva and Yunlong Shi for their appreciable contribution to sampling.

\section{REFERENCES}

1. Betteridge DJ. What is oxidative stress? Metabolism 2000;49: 3-8. https://doi.org/10.1016/S0026-0495(00)80077-3

2. Gutteridge JM. Lipid peroxidation and antioxidants as biomarkers of tissue damage. Clin Chem 1995;41:1819-28. https:// doi.org/10.1093/clinchem/41.12.1819

3. Hall ED. Efficacy and mechanisms of action of the cytoprotective lipid peroxidation inhibitor tirilazad mesylate in subarachnoid haemorrhage. Eur J Anaesthesiol 1996;13:279-89. https://doi.org/10.1046/j.1365-2346.1996.00980.x

4. Bottje WG, Wang S, Kelly FJ, Dunster C, Williams A, Mudway I. Antioxidant defenses in lung lining fluid of broilers: impact of poor ventilation conditions. Poult Sci 1998;77:516-22. https:// doi.org/10.1093/ps/77.4.516

5. Zhao Y, Flowers B, Saraiva A, Yeum KJ, Kim SW. Effect of social ranks and gestation housing systems on oxidative stress status, reproductive performance, and immune status of sows. J Anim Sci 2014;91:5848-58. https://doi.org/10.2527/jas.20136388

6. Renaudeau D, Noblet J. Effects of exposure to high ambient temperature and dietary protein level on sow milk production and performance of piglets. J Anim Sci 2001;79:1540-8. https://doi.org/10.2527/2001.7961540x

7. Black JL, Mullan BP, Lorschy ML, Giles LR. Lactation in the sow during heat stress. Livest Prod Sci 1993;35:153-170. https:// doi.org/10.1016/0301-6226(93)90188-N

8. Renaudeau D, Quiniou N, Noblet J. Effects of exposure to high ambient temperature and dietary protein level on performance of multiparous lactating sows. J Anim Sci 2001;79: 1240-9. https://doi.org/10.2527/2001.7951240x

9. Flowers B, Day BN. Alterations in gonadotropin secretion and ovarian function in prepubertal gilts by elevated environmental temperature. Biol Reprod 1990;42:465-71. https://doi. org/10.1095/biolreprod42.3.465

10. Zhang H, Wang Z, Liu G, He J, Su C. Effect of dietary fat supplementation on milk components and blood parameters of early-lactating cows under heat stress. Slovak J Anim Sci 2011;44:52-8.

11. Wegner K, Lambertz C, Das G, Reiner G, Gauly M. Climatic effects on sow fertility and piglet survival under influence of a moderate climate. Animal 2014;8:1526-33. https://doi.org/ $10.1017 /$ S1751731114001219

12. Ji F, Wu G, Blanton JR, Kim SW. Weight and compositional changes in pregnant gilts and its implication to nutrition. J Anim Sci 2005;83:366-75.

13. Kim SW, Wu G. Regulatory role for amino acids in mammary gland growth and milk synthesis. Amino Acids 2009;37:8995. https://doi.org/10.1007/s00726-008-0151-5

14. Berchieri-Ronchi CB, Kim SW, Zhao Y, Correa CR, Yeum KJ, Ferreira ALA. Oxidative stress status of highly prolific sows during gestation and lactation. Animal 2011;5:1774-9. 
https://doi.org/10.1017/S1751731111000772

15. Committee on Nutrient Requirements of Swine, National Research Council. Nutrient requirements of swine. 11th ed. Washington, DC, USA: National Academy Press; 2012.

16. Shen YB, Weaver AC, Kim SW. Effect of feed grade L-methionine on growth performance and gut health in nursery pigs compared with conventional DL-methionine. J Anim Sci 2014;92:5530-9. https://doi.org/10.2527/jas.2014-7830

17. Weaver AC, Kim SW. Supplemental nucleotides high in inosine 5-monophosphate to improve the growth and health of nursery pigs. J Anim Sci 2014;92:645-51. https://doi.org/10.2527/jas. 2013-6564

18. Chaytor AC, See MT, Hansen JA, de Souza ALP, Middleton TF, Kim SW. Effects of chronic exposure of diets with reduced concentrations of aflatoxin and deoxynivalenol on growth and immune status of pigs. J Anim Sci 2011;89:124-35. https:// doi.org/10.2527/jas.2010-3005

19. Huynh TTT, Aarnink AJA, Verstegen MWA, et al. Effects of increasing temperatures on physiological changes in pigs at different relative humidities. J Anim Sci 2005;83:1385-96. https://doi.org/10.2527/2005.8361385x

20. Botto L, Lendelova J, Strmenova A, Reichstadterova T. The effect of evaporative cooling on climatic parameters in a stable for sows. Res Agric Eng 2014;60:S85-91. https://doi.org/10. 17221/40/2013-RAE

21. Seedorf J, Hartung J, Schroder M, et al. Temperature and moisture conditions in livestock buildings in Northern Europe. J Agric Eng Res 1998;70:49-57. https://doi.org/10.1006/jaer. 1997.0284

22. Britt JH, Szarek VE, Levis DG. Characterization of summer infertility of sows in large confinement units. Theriogenology 1983;20:133-40. https://doi.org/10.1016/0093-691X(83) 90032-8

23. Robertshaw D. The environmental physiology of animal production. In: Clark JA, editor. Environmental aspects of housing for animal production. London, UK: Butterworths; 1981. p. 3-17.

24. Ozawa M, Hirabayashi M, Kanai Y. Developmental competence and oxidative state of mouse zygotes heat-stressed maternally or in vitro. Reproduction 2002;124:683-9. https:// doi.org/10.1530/rep.0.1240683

25. Matsuzuka T, Ozawa M, Nakamura A, Ushitani A, Hirabayashi M, Kanai Y. Effects of heat stress on the redox status in the oviduct and early embryonic development in mice. J Reprod Dev 2005;51:281-7. https://doi.org/10.1262/jrd.16089

26. Mujahid A, Akiba Y, Toyomizu M. Acute heat stress induces oxidative stress and decreases adaptation in young white leghorn cockerels by downregulation of avian uncoupling protein. Poult Sci 2007;86:364-71. https://doi.org/10.1093/ ps/86.2.364

27. Mujahid A, Akiba Y, Warden CH, Toyomizu M. Sequential changes in superoxide production, anion carriers and substrate oxidation in skeletal muscle mitochondria of heat-stressed chickens. FEBS Lett 2007;581:3461-7. https://doi.org/10.1016/ j.febslet.2007.06.051

28. Karowicz-Bilinska A, Suzin J, Sieroszewski P. Evaluation of oxidative stress indices during treatment in pregnant women with intrauterine growth retardation. Med Sci Monit 2002;8: CR211-6.

29. Toy H, Camuzcuoglu H, Arioz DT, Kurt S, Celik H, Aksoy N. Serum prolidase activity and oxidative stress markers in pregnancies with intrauterine growth restricted infants. J Obstet Gynaecol Res 2009;35:1047-53. https://doi.org/10. 1111/j.1447-0756.2009.01063.x

30. McGlone JJ, Von Borell EH, Deen J, et al. Reviews: Compilation of the scientific literature comparing housing systems for gestating sows and gilts using measures of physiology, behavior, performance, and health. Prof Anim Sci 2004;20: 105-17. https://doi.org/10.15232/S1080-7446(15)31285-7 